\title{
New Inscriptions from Northeast Phrygia: The Cult of Hosios and Dikaios
}

\author{
Hale GÜNEY*
}

\section{Introduction}

Since 2014, I have been conducting an epigraphic survey of more than half of the province of Eskişehir in central Anatolia in Turkey, an area which lies between the cities of Juliopolis, Dorylaion, Gordion and Amorion and which includes the imperial estate Choria Considiana as well as the cities Colonia Germa and Pessinous, Akkilaion and Midaion. ${ }^{1}$ The question of which city or estate the first survey area (Mihalıççı County) belongs to is an important issue as none of the inscriptions found so far bear a place name, such as that of an estate or city. ${ }^{2}$ Juliopolis, a city located in Gülşehri, $2 \mathrm{~km}$ away from Çayırhan in the modern province of Ankara, was the closest neighbouring city. ${ }^{3}$ The territory of Juliopolis, however, is difficult to ascertain since the city was flooded after the construction of the Saryyar Dam on the Sakarya river (ancient Sangarios) between 1951 and $1956 .{ }^{4}$ The city was situated to the north of the Sangarios river with the Skopas stream (Aladağ Çay) to its east. ${ }^{5}$ Its main neighbours were Dorylaion (Eskişehir) to the southwest, Claudiopolis (Bolu) to the north and Göynük, which was in the territory of Nicaea (İznik), to the west. ${ }^{6}$ Some inscriptions were found during an epigraphic survey conducted by the Anatolian Civilisations Museum in Çayirhan and Nallhan (which were principal parts of the territory of Julipolis during the Roman Imperial period), but they do not provide evidence about the territorial borders of Juliopolis. ${ }^{7}$ To date, the inscriptions found in our survey do not reveal any territorial connection with Juliopolis. We

\footnotetext{
${ }^{*}$ Hale Güney, Postdoctoral Fellow, University of Cologne, Institute of Historical Studies - Ancient History (hgueney1@uni-koeln.de).

Eskişehir Province Mihalıççık, Mahmudiye, Alpu, Çifteler, Beylikova and Sivrihisar Counties Epigraphic Survey Project was approved by the Turkish Ministry for Culture and Tourism. The survey staff consisted of Hale Güney (Project Director), Erman Yanık (Research Assistant), Murat Dirican (specialist in Archeometry) and Süleyman Güney (Driver and Guide). I would like to express my sincere thanks to the Ministry and to its representatives for their interest and contribution to the season's successful outcome. I am grateful to Alfried Krupp von Bohlen und Halbach Stiftung and the University of Cologne for hosting me and providing me a fellowship to prepare inscriptions for publication. I would like to thank Erman Yanı for all his help in recording inscriptions during the survey. I thank to local people in Otluk and Kayı villages for their help. I am much obliged to Stephen Mitchell, Walter Ameling and N. Eda Akyürek Şahin for their comments which helped to improve this article. I am indebted to Hansgerd Hellenkemper for kindly informing me about Byzantine architectural elements emerged in the context of inscriptions.

${ }^{1}$ Talbert 2000, Phrygia, map 62, http://pleiades.stoa.org/places/609442, last accessed: 28.03.2018.

${ }^{2}$ Only the names of few local communities and villages are known from the inscriptions found in our area.

${ }^{3}$ Ruge 1917, 102; Strobel 1999, 18-19; Marek 2000, 129-135.

${ }^{4}$ Onur 2014b, 66.

${ }^{5}$ Belke 1984, 181-182.

${ }^{6}$ Dönmez Öztürk - Öztürk 2015, 243.

${ }^{7}$ Avcu 2016, 162-168; Avcu - Doğan 2014, 85-99; Onur 2014a, 101-113; Onur 2014b, 65-83; the museum has also conducted excavations in Gülşehri, at the necropolis of Juliopolis, since 2009, Arslan 2014, 13-24.
} 
followed up our 2014 survey with further fieldwork in the following year, and, although our 2015 survey in this area was focused on exploring the territorial extent and connections of Juliopolis to this Bithynian-Galatian border area, no evidence to claim any territorial extension and connections was identified. Also, as the Sangarios River was a natural border between Galatia and Bithynia, we need to consider other territorial connections. ${ }^{8}$ It can, however, be proposed that some part of the area of discovery seems to have been the northern part of the Choria Considiana, which covered an area of fertile land in northeastern Phrygia. ${ }^{9}$ The estate lay in the province of Galatia, north-east of the ancient cities of Dorylaion (modern Eskişehir), Midaion and Akkilaion. The Sangarius River separated the estate from Bithynia, where the closest city was Juliopolis, on the Bithynian-Galatian border. Babadat, Mülk and Nasreddin Hoca villages, which are east of modern Sivrihisar, lay in the territory of Colonia Germa which was in Galatia. ${ }^{10}$ The Choria Considiana, an estate originally owned by a family of Italian origin which passed into imperial hands, is named in a single inscription previously found in Yukarı İğde Ağaç village in Beylikova County, to the south of Mihalıççı County. ${ }^{11}$ The inscription records the erection of a temple and statues dedicated by Eutyches, oikonomos of the Choria Considiana under Marcus Aurelius and Commodus between AD 177-180. ${ }^{12}$

A later account, Theodore of Sykeon in the $7^{\text {th }}$ century refers that the territory of Juliopolis was expanding towards Akreina (modern İkizafer) and Phyle (Beyköy) which are located in the eastern part of our survey area. ${ }^{13}$ An epigraphic analysis made by Stephen Mitchell, however, shows that the ancient villages of Akreina (Ikizafer/Ikikilise) and Phyle (Beyköy), were apparently part of another estate, belonging to the Roman senatorial family of the Plancii, which was situated to the east of the Choria Considiana during the Roman Imperial period. ${ }^{14}$ Both estates neighboured the small cities of Akkilaion, and Colonia Germa, as well as Juliopolis.

This paper presents four new inscriptions found in Kayı and Otluk villages and their vicinities located in Mihalıççı County. It also includes one inscription (no. 5) which was incompletely published by Anderson. An inscription which was found by our team indicates the existence of another estate belonged to a veteran and his son around Otluk village. It seems likely that Otluk village and surroundings were not a part of the Choria Considiana. Kayı and Yukarı Dudaş villages which are only few kilometres away Yukarı İğde Ağaç village, mentioned above, apparently were in the territory of the Choria Considiana. In the following second part, a catalogue of inscriptions is presented followed by an analysis and conclusion.

\section{Catalogue}

\section{Cat. No: 1 (Figure 1 a-b)}

Inv. No. 28; H-W: 0.37-0.80; m T: 0.27; m L: $2.3 \mathrm{~cm}$; Findspot: Kayapınar, $2.2 \mathrm{~km}$ northeast of Otluk village. The inscriptions were found in a church here which emerged during the construction

\footnotetext{
${ }^{8}$ Güney 2016, 127-128.

9 Talbert 2000, Phrygia, map 62, http://pleiades.stoa.org/places/609442, last accessed: 28.03.2018.

${ }^{10}$ Mitchell 1974, 27-39. http://dx.doi.org/10.2307/299258; Niewöhner et al. 2013, 97-136. http://dx.doi. org/10.1017/S0066154613000069.

${ }^{11}$ RECAM II 34; SEG 1982, 1263.

${ }^{12}$ RECAM II 34.

${ }^{13}$ Vita Theodore of Sykeon I, 79.

${ }^{14}$ Belke 1984, 120; 175-6; 215; Mitchell 1974, 27-39.
} 
of village road. The site was registered as church in 1981. The remains of the church and some marble blocks are still visible. ${ }^{15}$ On the walls of the church and around it, the stelae bearing inscriptions and also stelae only with depictions have been found. This is not surprising as the vast area to the north and south of the church site, called Köçekkıran and Darboğaz were also registered as necropolis area in 1981. These stelae apparently were used as spolia for the church construction later.

Altar of grey marble, above the moulding a pediment with a relief (broken at top), the relief shows Helios (?) holding bridles of four horses. The stone is broken at the bottom.

\begin{tabular}{|c|c|}
\hline \multirow{3}{*}{2} & 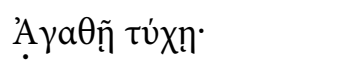 \\
\hline & 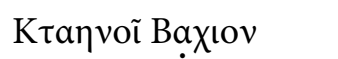 \\
\hline & $v$ \\
\hline \multirow{3}{*}{4} & 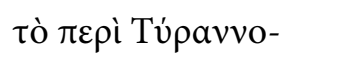 \\
\hline & 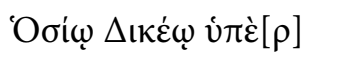 \\
\hline & $\dot{\varepsilon} \alpha \tau \tilde{\omega} \nu \kappa \grave{\varepsilon} \tau \tilde{\omega} \nu i \delta[i \hat{\omega} \omega \nu]$ \\
\hline \multirow[t]{2}{*}{6} & $\varepsilon \dot{x} \chi \eta \dot{v} v, \dot{\varepsilon} \pi \epsilon \mu[\varepsilon \lambda \mathrm{o}]-$ \\
\hline & 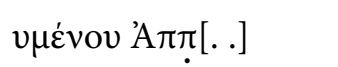 \\
\hline \multirow[t]{2}{*}{8} & 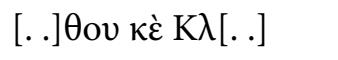 \\
\hline & {$[\ldots] \tau v \rho[\ldots]$} \\
\hline
\end{tabular}

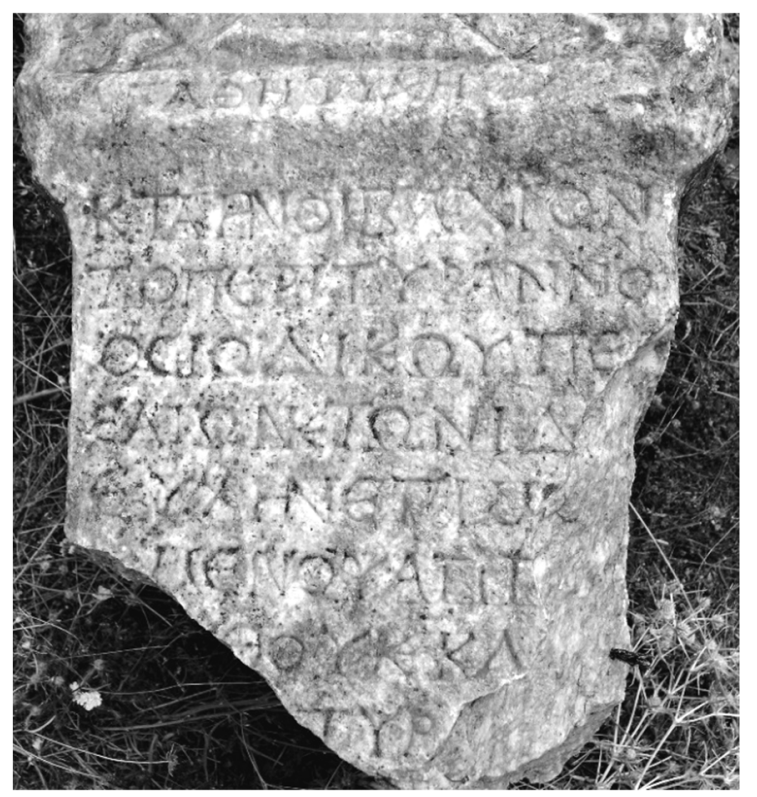

With good fortune! The Ktaenoi Bachion around Tyrannos performed a vow for Hosios Dikaios on behalf of themselves and their families; App(as?) son of (Anthos?) and Cl(audius) son of Tyrannos?. . . took care of it.

As the motive of standing Helios on a quadriga occurs only in Dorylaion and its surroundings on the monuments of Hosios and Dikaios, one can expect him here, too. ${ }^{16}$ Ligatures can be found in

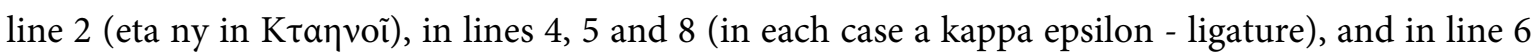

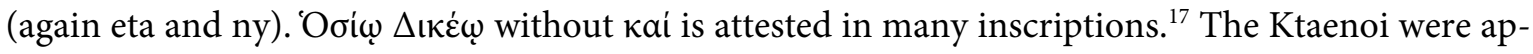

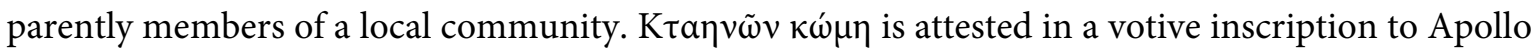
Alsenos near Acmonia which is about $240 \mathrm{~km}$ away from our survey area. ${ }^{18}$ The village seems to have been located near Acmonia. It is less likely that this village near Acmonia and the community in our survey area are the same. Such communities and phylai are frequently attested as offering votives to Hosios and Dikaios in the Phrygia. ${ }^{19}$ Bachos as a name ${ }^{20}$ and a community related to the

\footnotetext{
${ }^{15}$ See the report in: Sivas - Sivas 2005, 40.

${ }^{16}$ Ricl 1991, no. 20; Ricl 1992a, no. 1; Ricl 1992b, no. 5. Akyürek Şahin 2004b, 144-145.

${ }^{17}$ Ricl 1991, No. 1, 20, 21, 29, 30, 35, 37, 47, 48, 57, 58, 60, 61, 62, 63, 64, 67, 70, 72, 80, 88, 89.

${ }^{18}$ Drew-Bear 1976, 250 no. 4.

${ }^{19}$ Masikenoi in the territory of Dorylaion, Erten - Sivas 2011, 185-196; Dedications made by the member of phyle Artemeisias, Phyle Serapias; Ricl 2008, 570, no. 13, 16. In our survey area there is apparently one
} 


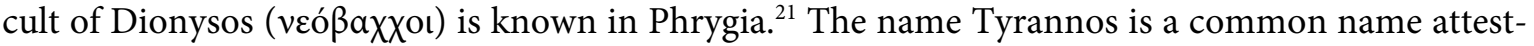
ed in the region. ${ }^{22}$ Lines between 7-9, one expects all names in genitive form. As the stone was damaged from both sides it is difficult to make certain restoration for lines 7-9. After Appas in line $7^{23}$, Anthos or Paithos can be suggested as patronym which are known in the region. ${ }^{24}$

\section{Cat. No: 2 (Figure 2 a-b)}

Inv. No. 43; H-W: 0.38-1.69 m; T: 0.38 m; L: 3 cm; Findspot: In front of a private house in Kay1 village. This inscription (along with no. 3) was originally found in Oğuz Pınarı which is on the road between Kayı and Aydınlar villages. They were brought to the village later for protection.

Grey limestone altar bearing a votive inscription inscribed at top and bottom with mouldings at top and bottom.

\begin{tabular}{|c|c|}
\hline & 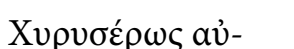 \\
\hline & тократо́ $\rho \omega \nu$ \\
\hline & 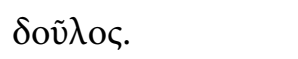 \\
\hline \multirow{3}{*}{4} & $v a c$ \\
\hline & 'Ало $\lambda \lambda \omega^{\prime} v \iota$ 'Oб'- \\
\hline & 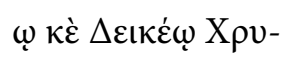 \\
\hline \multirow[t]{2}{*}{6} & $\sigma \varepsilon \dot{\varepsilon} \rho \omega \varsigma \kappa \grave{\varepsilon} \kappa \omega \dot{\omega} \mu \eta[\tau]$ \\
\hline & 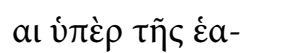 \\
\hline \multirow[t]{2}{*}{8} & $v \tau \tilde{\omega} \nu \sigma \omega \tau \eta \rho \dot{-}-$ \\
\hline & $\alpha \varsigma a ̉ v \varepsilon \dot{\varepsilon} \sigma \tau[\eta] \sigma \alpha \nu$ \\
\hline 0 & eủxác. \\
\hline
\end{tabular}
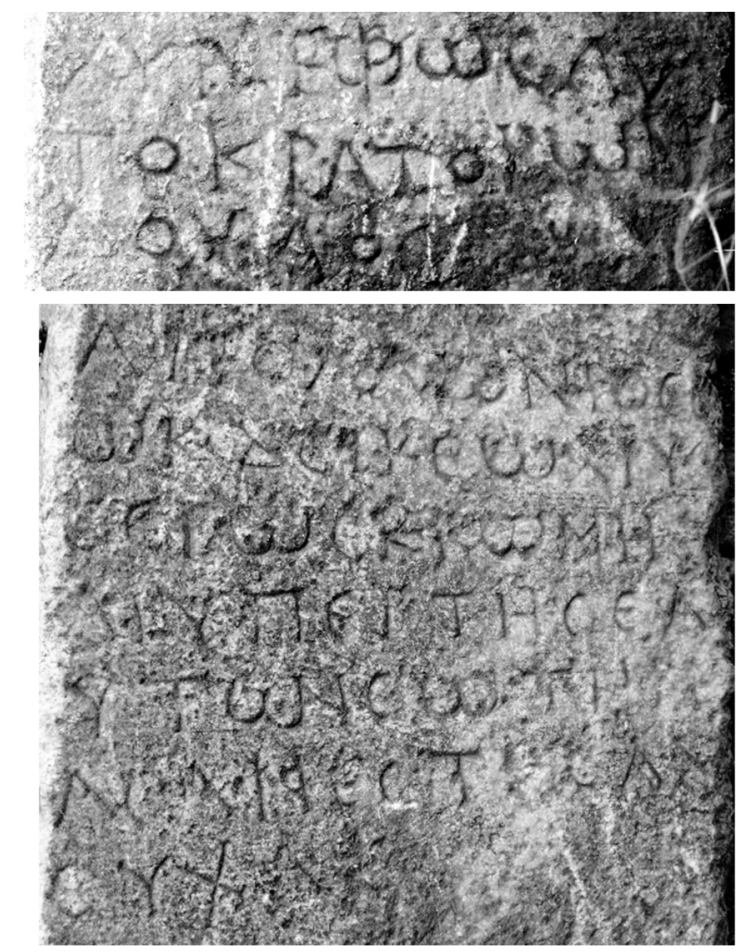

Chryseros, slave of the emperor. Chryseros and the villagers performed a vow to Apollo, Hosios and Dikaios and set this up for their safety.

community which was previously attested in Akreina (modern İkizafer). See, a vow to Zeus Akreinenos by the (-)nobantini: RECAM II 75.

${ }^{20}$ MAMA V 168.

${ }^{21}$ This votive inscription to Dionysos was found in Avdan near Eskişehir. It was dedicated by Mystai Koroseanoi Neobachchoi. Haspels 1971, 354, 144; The cult of Dionysos is attested in our survey area in Sarryar village, $45 \mathrm{~km}$ away from Otluk village: RECAM II 155.

\footnotetext{
${ }^{22}$ RECAM II 382; MAMA IX 133, 426, 428.

${ }^{23}$ MAMA IX 184; RECAM II 299.

${ }^{24}$ Anthos in Nacolea, MAMA V 204; Paithos in Pessinous, IK Pessinous 110.
} 
The surface of the inscription at the top bears traces of letters. There are two lambdas which are barely visible. Perhaps the engraver first wanted to inscribe the inscription starting with Apollo below,

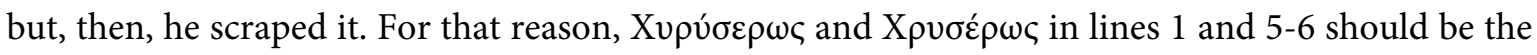
name of the same person. A parallel for kappa letter inscribed for $\Delta \varepsilon \varepsilon \kappa \varepsilon \dot{\omega}$ can be found in another fragment of a votive inscription to Hosios and Dikaios which came from the sanctuary at Yaylababa village near Nacolea. ${ }^{25}$ Ligatures can be found in $\kappa \dot{\varepsilon}$ (kappa and epsilon) in lines 5 and 6 and in $\dot{\varepsilon} \alpha \tau \tau \tilde{\omega} v$ (omega and ny) in line 8. The name Chryseros is male name attested in Bithynia and Caria. ${ }^{26}$ The find spot is only 13-14 km away from Yukarı İğde Ağaç village where erection of a temple and statues dedicated by Eutyches, oikonomos of imperial estate, the Choria Considiana under Marcus Aurelius and Commodus between AD 177-180 was found. ${ }^{27}$ This estate was run by an imperial slave as oikonomos. Chryseros therefore must have been another imperial slave from the Choria Considiana, some time after Eutyches (based on letter forms on two inscriptions), but there is no reason to believe that he was oikonomos, too.

\section{Cat. No: 3 (Figure 3 a-b)}

Inv. No. 44; H-W: 0.37-1.30 m; T: 0.36 m; L: 2,5 cm; Findspot: In front of a private house in Kay1 village, brought from Oğuz Pınarı.

Grey limestone altar bearing a votive inscription with mouldings at top and bottom, damaged heavily at right and left.

\begin{tabular}{|c|c|}
\hline \multirow{3}{*}{2} & {$[\ldots-\ldots$ - A $\pi] \mathrm{o} \lambda \lambda \omega{ }^{\prime} \nu[\mathrm{\iota}]$} \\
\hline & 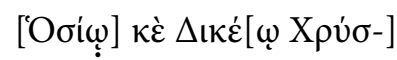 \\
\hline & {$[\dot{\varepsilon} \rho] \omega \varsigma \kappa \grave{\varepsilon} \kappa[\dot{\omega} \mu \eta \tau \alpha \mathrm{l}]$} \\
\hline 4 & {$[\dot{v} \pi] \dot{\varepsilon} \rho \tau[\tilde{\eta} \varsigma]$} \\
\hline & $\kappa \omega[\mu \tilde{\eta} \varsigma]$ \\
\hline 6 & {$[\dot{\alpha}] v \dot{\varepsilon} \sigma[\tau \eta \sigma \alpha \nu]$} \\
\hline & {$[\varepsilon \dot{x}] \dot{\alpha}[\varsigma]$.} \\
\hline
\end{tabular}

Chryseros? and the villagers? performed a vow to Apollo, Hosios and Dikaios and set this up for their village?

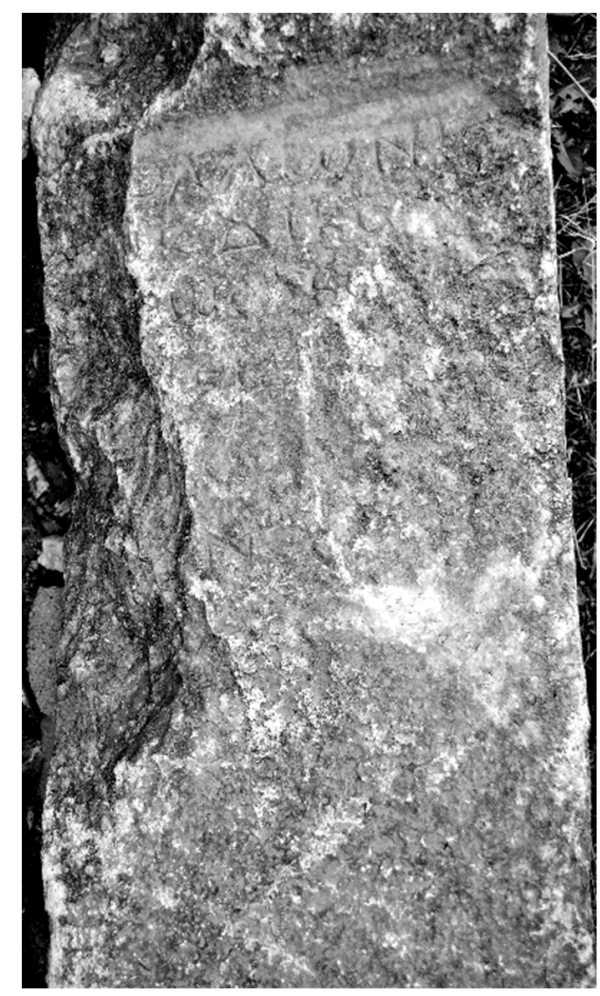

\footnotetext{
${ }^{25}$ Chi letter in عủxńv: Ricl 1991, p. 175 , no. 25 , tab. VII.

${ }^{26}$ Öztürk 2016, 290-291; Aydaş 2009, 116.

${ }^{27}$ RECAM II 34.
} 
This inscription was found together with no. 2 in the same place called Oğuz Pınarı which is on the road between Kayı and Aydınlar villages. As it is heavily damaged, full restoration of the inscription is impossible. It seems that the stone carries the similar inscription as in no. 2. Ligatures can be

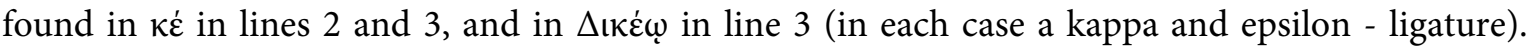
Kappa in $\Delta$ เ $\varepsilon \dot{\omega}$ here is in its standard form, not like the form as in no. 2.

\section{Cat. No: 4 (Figure 4)}

Inv. No. 45; H-W: 0.39-0.51 m; T: 0.32 m; L: $2,5-3 \mathrm{~cm}$; Findspot: In courtyard of village mosque in Kayı village, brought from Yukarı Dudaş.

Grey marble altar bearing a votive inscription with mouldings at top, barely visible male figure (Helios or Apollo) riding a horse depicted below the inscription, fitted to the ground as used as pedestal for a flowerpot.

$$
\tau \eta \sigma \varepsilon v[\ldots] \text { ov } \dot{v} \pi[\grave{\varepsilon} \rho]
$$

$4 \quad \tau \tilde{\eta} \varsigma[\ldots] \quad \alpha[-] \varsigma$

$N$. N. set this up (and performed a vow)

to Hosios and Dikaios for their - . - -

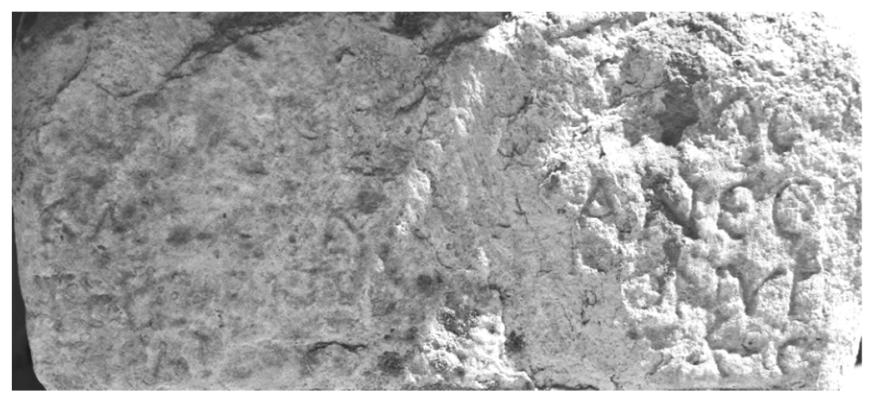

Villagers in Kayı informed that this inscription and no. 5 were brought from village called Yukarı Dudaş which is located $15 \mathrm{~km}$ away from Kayı village. Indeed, Anderson records the next inscription (no. 5) which was found in an old cemetery 36 minutes to the north of Yukarı Dudaş. ${ }^{28} \mathrm{He}$, however, did not mention this inscription.

\section{Cat. No: 5 (Figure 5 a-c)}

Inv. No. 46; H-W: 0.35-0.68,5 m; T: $0.43 \mathrm{~m}$; L: $3 \mathrm{~cm}$; Findspot: In courtyard of village mosque in Kayı village, brought from Yukarı Dudaş.

Publication: Anderson 1899, 80 no. $44=$ Ricl 1991, no. 86.

Grey marble altar bearing a votive inscription with mouldings at top; relief of two figures clasping hands? and wearing chiton below the inscription, one of which holds the staff of justice; a bunch of grape with long stalk on the left side of the stone, a crater on the right depicted; ${ }^{29}$ fitted to the ground as used as pedestal for a flowerpot.

\footnotetext{
${ }^{28}$ Anderson 1899, 80 no. 44.

${ }^{29}$ For depictions of vines and grapes on some dedications to Hosios and Dikaios as protectors of viticulture, see Ricl 1991, no. 26, 33.
} 
$[A] \gamma \alpha \theta \tilde{n} \tau u ́-$

2 $\chi \eta^{\cdot}$

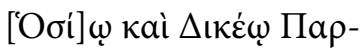

4

$[\ldots] \delta\llcorner\alpha \tau \varepsilon \dot{v} \pi \grave{\varepsilon} \rho \dot{\varepsilon} \alpha u-$

$[\tau] \tilde{\omega} v \kappa \grave{\varepsilon} \tau \tilde{\omega} v i \delta \dot{\delta} \omega v$

$6 \pi \alpha v \tau \tilde{\omega} v \varepsilon \dot{x} \times \eta ́ v$.

With good fortune! N. N. ... on behalf of themselves and their whole family performed a vow to

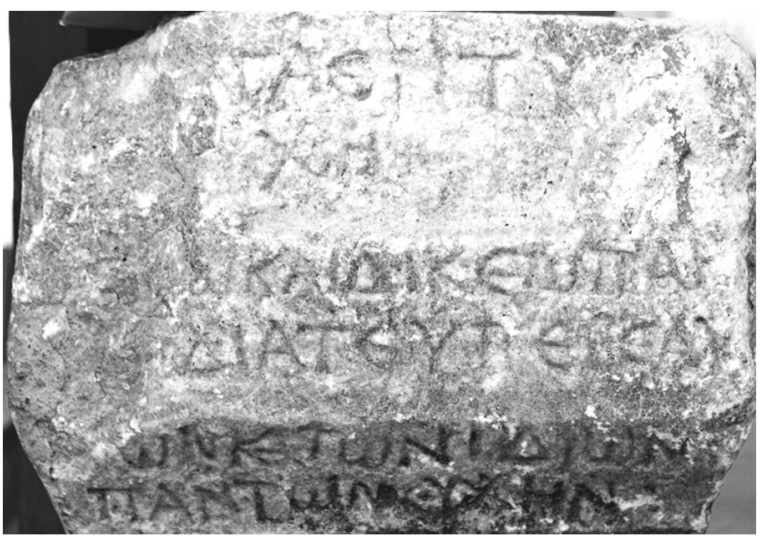
Hosios and Dikaios.

Anderson recorded this inscription in old cemetery 36 minutes to the north of Yukarı Dudaş. ${ }^{30}$ However, the beginning of the inscriptions, "with good fortune" and depictions on the right and left side of the stone are all missing in his publication. Anderson suggests the word in lines 2-3 as $\pi \alpha \rho[\alpha \gamma \omega] \delta$ (ã $\tau \varepsilon$ which means wearers of $\pi \alpha \rho \alpha \gamma \tilde{\omega} \delta \eta \varsigma .{ }^{31}$ There is ligature in $\kappa \varepsilon \dot{\varepsilon}$ in line 5 (kappa and epsilon).

\section{Analysis and Conclusion}

The last three decades have witnessed increasing number of publications on the cult of Hosios and Dikaios. The majority of the already known dedications came from northwest Phrygia and northeast Lydia. The attestations from Lydia are less in number. Epigraphic evidence for the cult of Hosios and Dikaios is mostly known from the votive inscriptions found in northwest Phrygia (modern Kütahya and Eskişehir). As the cult is intensively attested in Anatolia, it is accepted that the cult is originated from Asia Minor. ${ }^{32}$ Furthermore, the current evidence much weighed to Phrygia, as a region where this cult was originated. The cult, however, is less examined within archaeological context in which votive inscriptions emerged.

This paper presents new votive inscriptions from north-eastern edge of Phrygia where the existence of this cult is less known. ${ }^{33}$ Cult organization and architectural structure of Hosios and Dikaios is not well known. The discovery of forty small votive stelai in Yaylababa village, $22 \mathrm{~km}$ southwest of Kotiaion (modern Kütahya), is interpreted that also a sanctuary has been localised in this village. An analysis made by Marijana Ricl on the reliefs of the sanctuary of Yaylababa shows that the gods were esteemed as two distinct entities while they were considered as one deity in Lydia. ${ }^{34}$ Both cases can be found for the cult of Hosios and Dikaios presented here (as one entity in nos. 1, 4 and two entities in no. 5 in the catalogue).

In our catalogue, the first place where the first inscription was found is Kayapinar (no. 1), a site that was registered as church in 1981 (figure 6). In 2004, Taciser and Hakan Sivas examined the site during their archaeological survey and noted that inside the church, below the foundation-level, a hole

\footnotetext{
${ }^{30}$ Anderson 1899, 80 no. 44.

${ }^{31}$ Anderson 1899, 80 no. 44. It is noted by Mitchell that it is more likely to be an ethnic (RECAM II 45).

${ }^{32}$ Akyürek Şahin 2004a, 1-19.

${ }^{33}$ Only three inscriptions found in Yukarı Dudaş and Doğray villages, RECAM II 18, 44, 45.

${ }^{34}$ Ricl 1992, 71-125.
} 
was opened by illegal excavation/s. ${ }^{35}$ From there, broken funerary inscriptions and votive inscriptions emerged and scattered around as we also recorded during 2015 survey (figures 7-8). ${ }^{36}$ Besides the votive inscription under consideration (no. 1), one other votive inscription to Hosios and Dikaios found by Sivas' team also bears a name of another community. ${ }^{37}$ Only two votive inscriptions dedicated by two individuals would not be enough to accept the existence of a sanctuary, however there have been at least two communities who made offerings to Hosios and Dikaios in Kayapınar. This indicates that there was a kind of local sanctuary (or monumental altar) of the cult of Hosios and Dikaios in the place where the church was built later. This local sanctuary was then surrounded by a vast necropolis area which was also used after the construction of church. A reused grave stele with crosses observed in the site proves this. Our team discovered a marble quarry, just outside Otluk village, where traces of extraction can be seen clearly (figures 9). The marble used in Kayapinar had presumably been extracted from the quarry in close proximity to the site. Yet, a provenance analysis is needed for certainty.

The inscriptions no. 2-3 in our catalogue were found in situ in Oğuz Pınarı, a site located between Kayı and Aydınlar villages in Mihalıççı County. When the site was examined, tiles and pottery sherds could be clearly differentiated. This indicates the existence of a settlement or a farmstead here. This settlement was located next to a stone quarry where extraction traces are still visible (figures 10-11). Its grey crystalized limestone carries dark grey veins. A close examination shows that the stone used for inscriptions and the stone in the quarry resembles each others (figure $3 \mathrm{~b}$ ), but a provenance analysis should be made to reach certainty. Along with two inscriptions one more architectural piece is also found in Oğuz Pınarı (figure 12). This seems to be the middle window pillar of a double-window, e.g. for the central window of the apse in an early Christian/early Byzantine local church. ${ }^{38}$ The window divider which bears a christogram on one side (figure 12) and a staurogram on the other side (figure13) could be directed either to the inside or the outside of the church. The style indicates a date in the $5^{\text {th }}-6^{\text {th }}$ centuries $\mathrm{AD} .{ }^{39}$ If this is the case, then for the second time, the cult is attested within a later church context. Perhaps, the stone of window-divider first was used as an architectural element in the sanctuary or shrine of Apollo, Hosios and Dikaios here and later was reused for church.

Earlier votive inscriptions to Hosios and Dikaios are only attested in Yukarı Dudaş and Doğray villages in our survey area. ${ }^{40}$ The inscriptions in the catalogue, no. 4-5 were found in the courtyard of village mosque in Kayı (figures 4, $5 \mathrm{a}-\mathrm{c}$ ). Besides these votive offerings to Hosios and Dikaios, we observed an altar with bucrania in the mosque courtyard. We were told that the inscriptions were brought from Yukarı Dudaş, a village that is $15 \mathrm{~km}$ away from Kayı village. No. 4 seems to be a new addition to the cult of Hosios and Dikaios, while no. 5 was recorded by Anderson with missing letters and description in Yukarı Dudaş. Anderson found another inscription in Yukarı Dudaş in

\footnotetext{
${ }^{35}$ Sivas - Sivas 2005, 40.

${ }^{36}$ Sivas - Sivas 2005, 40.

${ }^{37}$ This inscription has not been attested at the site in our survey 2015. I would like to thank Hakan Sivas and Emre Erten for informing me about their discovery.

${ }^{38}$ For similar examples, see: Hellenkemper-Hild 1986, 78-80: Hacıömerli (no. 4), Batısandal (no. 5), Yanıkhan (no. 7); Belke 1984, 146-148: Mihaliç in Karadağ (north of Larende).

${ }^{39}$ I would like to thank Hansgerd Hellenkemper for his help.

${ }^{40}$ RECAM II 44, 18.
} 
the same cemetery, as no. 5, and it refers Apollo and Hosios as attentive gods. ${ }^{41}$ One other inscription again attested in the same village is a dedication to Helios at command of Apollo. ${ }^{42}$ There is one more fragmentary inscription attested in Aşağ 1 Dudaş dated to AD 247. This inscription only bears a name of a priest, Hermas to whom he made his service is not clear. ${ }^{43}$ All these evidences centred in Yukarı Dudaş might have been an indication of the existence of a local sanctuary to Apollo, Hosios and Dikaios in the village. ${ }^{44}$ However, inscriptions were not in situ and there is no more archaeological evidence to support this claim. It is hoped that our next survey which will focus on this area can help to answer this question in the light of the new evidence.

The inscriptions that emerged in situ in Otluk and Kayı villages were found in the vicinity of stone quarries. The availability of stone quarries at a short distance generally was an important factor for the building program as well as its use in funerary and votive contexts. The inhabitants used the marble and limestone for dedications in their immediate neighbourhood. The inhabitants of Phrygia notably took advantage of marble in their region, e.g. in Docimeum. By contrast to the rest of the empire, the abundance of marble allowed people even in lower social strata to use it for their funerals and dedications and express themselves. The same phenomenon occurs in the cases of Zeus Thallos, Zeus Ampelites and Zeus Andreas near the town of Appia in northern Phrygia where there were smaller marble quarries. ${ }^{45}$

The second conclusion is linked with an ongoing debate on Jewish influence on pagan notions of angeloi in which Hosios and Dikaios are also considered ${ }^{46}$ Hosios and Dikaios was found in company with Apollo and apparently Helios in our survey area. The cult of Apollo is also known to the east of the Choria Considiana in one votive and another funerary inscription for a priest of Apollo. ${ }^{47}$ The cult of Zeus with different epithets, Narenos, Sarnendenos, Akreinenos, Heptakomeiton, however, was the most important cult in this area. One of the most striking elements of the epigraphy of Phrygia is the large number of pre-Constantinian Christian inscriptions. In the region under consideration, however, no such inscriptions are known so far. There is evidence of Christianity in our area by the post-Contantinian period onwards. This raises the question of when Christianity began to make significant inroads into our region. In the state of the current evidence, it seems that the area encompassed, the Choria Considiana, the estate of the Plancii, and another estate apparently belonged to a veteran and his son around Otluk village remained pagan until Christianity became the official religion and then it was widely accepted. When the imperial authority and the people largely embraced the new religion, it seems that pagan sanctuaries/shrines were converted to church; or the stone available at these sites was used for the construction of church, later. Between paganism and the Christianity, there is apparently no transition (e.g. Montanism, Hypsistarianism or pre-Constantinian conversion) that can be seen in our region. There could be various reasons for this phenomenon. The settlement pattern in the region is village where local communities resided.

\footnotetext{
${ }^{41}$ RECAM II 44.

${ }^{42}$ RECAM II 47.

${ }^{43}$ RECAM II 49.

${ }^{44}$ Another votive inscription to Helios, Hosios and Dikaios and Apollo which was found in Akçakaya near Eskişehir provides depictions of each god; see Erten - Sivas 2011, 185-196.

${ }^{45}$ Drew-Bear - Thomas - Y1ldızturan 1999, 13-14; Masséglia 2013, 95-96.

${ }^{46}$ Sheppard 1980/1981, 77-100; See the latest article on this debate: Horsley - Luxford 2016, 141-183.

${ }^{47}$ RECAM II 74, 74a.
} 
One reason therefore could be the absence of any urban centre here, as a hub for the exchange not only of products, but also of ideas. When it comes to the existence of Jewish community or the cult of Theos Hypsistos ${ }^{48}$ to date, there is no inscription or evidence in the Choria Considiana and the Plancian estates. Dedication to Theos Hypsistos and the existence of Jews are found in the vicinity of the city of Germia further to the south. ${ }^{49}$ Another reason might be the existence of the Choria Considiana, an imperial estate belonged to the emperor. For that reason, the inhabitants may have favoured imperial religious mentality. However, this is not case all the time since there are other people in Phrygia working in imperial and private estates and converted to Christianity. ${ }^{50}$

The third and more general conclusion is related to the rapid increase in worship of the cult of Hosios and Dikaios during the second and third centuries in Phrygia. The earliest inscription mentioning Hosios and Dikaios found in Hadrianoutherai in Mysia seems to be dated to the first century $\mathrm{AD}$, perhaps earlier. The inscriptions to Hosios and Dikaios and Theos Hypsistos were frequently attested between c. 150-300 in Phrygia. ${ }^{11}$ Under the Principate, Montanism emerged with its own understanding of Christianity on one side, early Christian inscriptions dated to pre-Constantinian time came into existence on the other side in Phrygia. Within this religious setting, the impetus for the tendency to the cult of Hosios and Dikaios was not only the need for divine justice in rural countryside, ${ }^{52}$ but it was also a new interest in the cult of Hosios and Dikaios. This view is not a rejection of Jewish influence and later Christian impact on the cult of Hosios and Dikaios as an angel cult, thus, their influence on the religious mentality of pagans in Phrygia. Like the existence of Hypsistarians, serious competitors of early Christianity, ${ }^{53}$ the increase of votive offerings to the cult of Hosios and Dikaios seems to be a response of pagans in Phrygia to the Christianity and other monotheist trend. The pagans in Phrygia, a region where the inhabitants expressed their religious choice liberally, could have chosen Montanism, Christianity or Hypsistarianism. They, however, remained as pagan and apparently adapted the cult of Hosios and Dikaios in company with Apollo and Helios and promoted the concept of holy and just as opposed to other religious communities.

\footnotetext{
${ }^{48}$ There is one other votive inscription to the highest and greatest god found in Hidirlar village which was apparently in the territory of Juliopolis, approximately $25 \mathrm{~km}$ away from the sanctuary of Zeus Sarnendenos. Cattius Tergius offers an altar for the safety of his family and his oxen. Only the attributes of the god were mentioned in the inscription while the name was not inscribed. Christian Marek suggests that this god might have been Zeus Sarnendenos. Marek 2000, 129-135. However, no dedication to Zeus Sarnendenos found so far indicates his attributes.

${ }^{49}$ Mitchell 1993 II, 36; RECAM II 133, 141.

${ }^{50}$ Mitchell 1993 II, 40.

${ }^{51}$ Mitchell 1999, 109.

${ }^{52}$ Mitchell 1993 II, 25.

${ }^{53}$ Mitchell 2010, 197.
} 


\section{Bibliography}

Akyürek Şahin 2004a

N. E. Akyürek Şahin, Anadolu'da Hosios kai Dikaios Kültü (Kutsal ve Adil Tanr1), Arkeoloji ve Sanat 118, 2004, 1-19.

Akyürek Şahin 2004b ～N. E. Akyürek Şahin, Neue Weihungen für Hosios kai Dikaios, Gephyra $1,2004,135-148$.

Anderson 1899

J. G. C. Anderson, Exploration in Galatia cis Halym, JHS 19, 1899, 52134 and 318.

Arslan 2014

M. Arslan, Iuliopolis Nekropolü Kharon Sikkeleri, in: K. Dörtlük - O. Tekin - R. Boyraz Seyhan (eds.), First International Congress of the Anatolian Monetary History and Numismatics, İstanbul 2014, 13-24.

Avcu 2016

F. Avcu, Nallıhan Çevresinden Yeni Yazıtlar, in: B. Takmer - E. Akdoğu Arca - N. Gökalp (eds.), Vir Doctus Anatolicus. Studies in Memory of Sencer Şahin, İstanbul 2016, 162-168.

Avcu - Doğan 2014 F. Avcu - Y. Doğan, Epigraphic research around Juliopolis II: New inscriptions from Nallihan, Gephyra 11, 2014, 85-99.

Aydaş 2009

M. Aydaş, New Inscriptions from Strotenikeia and its territory, Gephyra $6,2009,113-130$.

Belke 1984

K. Belke, Galatien und Lykaonien (TIB 4), Vienna 1984.

Corsten 2012

Dönmez Öztürk -

Öztürk 2015

Drew-Bear 1976

T. Corsten - M. Ricl, A dedication to Herakles, Hosios and Dikaios and Chrysea Parthenos from the Kibyratis, Gephyra 9, 2012, 143-151.

F. Dönmez-Öztürk - H. S. Öztürk, Göynük ve Mudurnu'dan yeni yazitlar III, Cedrus 3, 2015, 243-256.

T. Drew-Bear, Local Cults in Graeco-Roman Phrygia, GRBS 17, 1976, 247-268.

Drew-Bear - Thomas - T. Drew-Bear - C. M. Thomas - M. Yildizturan, The Museum of AnaYildizturan 1999 tolian Civilizations: Phrygian Votive Steles, Ankara 1999.

Erten - Sivas 2011

E. Erten - H. Sivas, Eine Neue Weihung aus Phrygien, Epigr Anat 44, 2011, 185-196.

Güney 2016

H. Güney, New Inscriptions from Choria Considiana: Çalçak Roman necropolis, Anat Stud 66, 2016, 127-128.

Haspels 1971

C. H. E. Haspels, The Highlands of Phrygia. Sites and Monuments, Princeton 1971.

Hellenkemper - Hild H. Hellenkemper - F. Hild, Neue Forschungen in Kilikien (TIB 4), 1986 Vienna 1986.

Horsley - Luxford G. H. R. Horsley - J. M. Luxford, Pagan angels in Roman Asia Minor: 2016 revisiting the epigraphic evidence, Anat Stud 66, 2016, 141-183.

IK Pessinous

J. Strubbe, The Inscriptions of Pessinous (IK 66), Bonn 2005. 
MAMA V

MAMA IX

Marek 2000

Masséglia 2013

Mitchell 1974

Mitchell 1993

Mitchell 1999

Mitchell 2010

Niewöhner et al. 2013

Onur 2014a

Onur 2014b

Öztürk 2016

Petzl 1992

RECAM

Ricl 1990

Ricl 1991
C. W.W. Cox - A. Cameron, Monuments from Dorylaeum et Nacolea (MAMA 5), Manchester 1937.

B. Levick - St. Mitchell - J. Potter - M. Waelkens, Monuments from the Aezanitis (MAMA 9), London 1988.

C. Marek, Der höchste, beste, größte, allmächtige Gott. Inschriften aus Nordkleinasien, Epigr Anat 32, 2000, 129-146.

J. Masséglia, Phrygians in relief: trends in self-representation, in: P. Thonemann (ed.), Roman Phrygia: Culture and Society, Oxford 2013, 95-123.

St. Mitchell, The Plancii in Asia Minor, JRS 64, 1974, 27-39.

St. Mitchell, Anatolia: Land, Men and Gods in Asia Minor. I: The Celts and the Impact of Roman Rule; II. The Rise of the Church, Oxford 1993.

St. Micthell, The cult of Theos Hypsistos, in: P. Athanassiadi - M. Frede (eds.), Pagan Monotheism in Late Antiquity, Oxford 1999, 81148.

St. Mitchell, Further thoughts on the cult of Theos Hypsistos, in: S. Mitchell - P. van Nuffelen (eds.), One God: Pagan Monotheism in the Roman Empire, Cambridge 2010, 167-208.

P. Niewöhner - G. Dikilitaş - E. Erkul - S. Giese - J. Gorecki - W. Prochaska - D. Sarı - H. Stümpel - A. Vardar - A. Waldner - A. V. Walser - H. Woith (eds.), Bronze Age höyüks, Iron Age hilltop forts, Roman poleis and Byzantine pilgrimage in Germia and its vicinity. "Connectivity" and a lack of "definite places" on the central Anatolian high plateau, Anat Stud 63, 2013, 97-136.

C. Onur, Epigraphic research around Juliopolis III: Roman and Byzantine inscriptions from Doğandere and Juliopolis, Gephyra 11, 2014, 101-113.

F. Onur, Epigraphic research around Juliopolis I: a historical and geographical overview, Gephyra 11, 2014, 65-83.

H. S. Öztürk, Göynük ve Mudurnu'dan Yeni Yazıtlar IV, Cedrus IV, 2016, 287-297.

G. Petzl, Ein frühes Zeugnis für den Hosios-Dikaios-Kult (Ricl Nr. 103), Epigr Anat 20, 1992, 143-147.

RECAM. Regional Epigraphic Catalogues of Asia Minor.

M. Ricl, Le Sanctuaire des Dieux Saint et Juste a Yaylababa Köyü, Živa Antika 40, 1990, 157-177.

M. Ricl, Hosios kai Dikaios. Premiere Partie: Catalogue des inscriptions, Epigr Anat 18, 1991, 1-70. 
Ricl 1992a

Ricl 1992b

Ricl 2008

Ruge 1917

SEG

Sheppard 1980/1981

Sivas - Sivas 2005

Strobel 1999

Talbert 2000

Vita Theodore of Sykeon
M. Ricl, Hosios kai Dikaios. Seconde partie: Analyse, Epigr Anat 19, 1992, 71-125.

M. Ricl, Hosios kai Dikaios. Nouveaux monuments, Epigr Anat 20, 1992, 95-100.

M. Ricl, Newly Published and Unpublished Inscriptions for Hosios and Dikaios and their Contribution to the Study of the Cult, in: E. Winter (ed.), Vom Euphrat bis zum Bosporus. Kleinasien in der Antike. Festschrift für Elmar Schwertheim zum 65. Geburtstag II (Asia Minor Studien 65), Bonn 2008, 563-579.

W. Ruge, Iuliopolis, RE 10, 1917, 102.

Supplementum Epigraphicum Graecum, Leiden 1923-.

A. R. Sheppard, Pagan cults of angels in Roman Asia Minor, Talanta 12/13, 1980/1981, 77-100.

T. Sivas - H. Sivas, Eskişehir, Kütahya, Afyonkarahisar İlleri 2004 Yılı Arkeolojik Envanteri ve Yüzey Araştırması, Türkiye Bilimler Akademisi Kültür Envanteri Dergisi 4, 2005, 33-58.

K. Strobel, Iuliopolis, DNP 6, 1999, 18-19.

R. Talbert, The Barrington Atlas of the Greek and Roman World, Princeton 2000.

Vita Theodore of Sykeon, A. - J. Festugèire (ed.), Vie de Théodore de Sykéôn I. Texte grec II. Traduction, Commentaire et Appendice, Brussels 1970.

\section{Kuzey Doğu Phrygia’dan Yeni Yazıtlar: Hosios ve Dikaios Kültui \\ Özet}

Geçtiğimiz son otuz yılda artan sayıdaki adak yazıtlarının yayını sadece yazıtlarda tespit edilen ancak antik edebi eserlerde bahsedilmeyen Hosios kai Dikaios kültü hakkında bilinenleri arttırmıştır. Hosios kai Dikaios, yani kutsal ve adil tanrı bazen tek bir tanrı bazen de iki ayrı tanrı olarak kabul edilmiştir ve günümüze ulaşan yazıtların büyük çoğunluğu Phrygia ve Lydia bölgelerinde bulunmuştur. Pek çok nedenden dolayı söz konusu kült, adak yazıtlarının bulunduğu arkeolojik bağlamda çok fazla incelenememiştir. Oysa bu eksiklik kültün organizasyonu gibi pek çok konudaki soruyu yanıtlamayı zorlaştırmaktadır. Bu makale 2014 yılından bu yana kuzeydoğu Phrygia'da yürütülen epigrafik yüzey araştırması kapsamında bulunan dört yeni adak yazıtını incelemektedir. Makale ayrıca daha önce Anderson tarafından eksik olarak yayımlanmış beşinci bir yazıtı da içermektedir. Bu yazıtlar Eskişehir ilinin Sakarya ve Porsuk nehirleri arasında kalan Mihalıççık ilçesine bağlı Otluk ve Kayı köylerinde bulunmuştur. Bu çalışmada Hosios Dikaios kültü adak yazıtları, külte ait muhtemel kutsal alan ve söz konusu yazıtların sağlandığı antik taş ocakları da incelenerek değerlendirilmiştir. Makale tarihi coğrafyayı içeren birinci bölüm, yazıtların sunulduğu katalog bölümü ve son olarak analiz ve sonuç bölümü olmak üzere üç ana bölümden oluşur. 
No. 1: 'Hayırlı olsun! Tyrannos etrafındaki Ktaenoi Bachion kendileri ve aileleri adına bu adağı Hosios (ve) Dikaios'a sundular; (Anthos?'un oğlu) App(as?) ve (Tyrannos?'un oğlu) Kl(audius) . . . . . işlemleri yürüttüler.'

No. 2: 'İmparatorların kölesi Khryseros. Khryseros ve köy sakinleri bu adağı Apollon ile Hosios ve Dikaios'a kendi esenlikleri için diktiler.'

No. 3: 'Khryseros ve köy sakinleri? bu adağı Apollon ile Hosios ve Dikaios'a köyleri için? diktiler.'

No. 4: 'Hosios ve Dikaios'a filanca ve filanca bu adağı ... . için diktiler.'

No. 5: 'Hayırlı olsun! Filanca ve filanca bu adağı kendileri ve aileleri için Hosios ve Dikaios'a diktiler.'

Anahtar Sözcükler: Hosios ve Dikaios, Phrygia, Galatia, Choria Considiana, Eskişehir.

\section{New Inscriptions from Northeast Phrygia: The Cult of Hosios and Dikaios}

\section{Abstract}

The last three decades have witnessed increasing number of publications on the cult of Hosios kai Dikaios, Holy and Just, a cult predominantly found in Phrygia and Lydia worshipped together with Helios and Apollo. Due to various reasons, this cult, however, is less examined within archaeological context in which votive inscriptions emerged. The lack of archaeological context prevents us to evaluate the origins and organization of the cult under consideration. This paper presents the initial results of an epigraphic survey carried out since 2014 in northeast Phrygia. The first surveyed area today encompassing Mihalıççk County in Eskişehir province is located between the Sakarya (Sangarios) river to the north and the Porsuk (Tembris) river to the south. This paper focuses on two groups of new inscriptions found in Kayı and Otluk villages and their vicinities located in Mihalıççı County. It also includes one inscription (no. 5) which was incompletely published by Anderson. The discovery of four inscriptions offers some new information about the cult of Hosios and Dikaios, possible locations for the sanctuary/shrine of the cult and the provenance of the stone used for votive inscriptions in northeast Phrygia. The paper begins by laying out the historical geography of survey area, and then it presents the inscriptions and commentaries. It finally evaluates the evidence with reference to archaeological context including general historical conclusions.

Keywords: Hosios and Dikaios, Phrygia, Galatia, Choria Considiana, Eskişehir. 


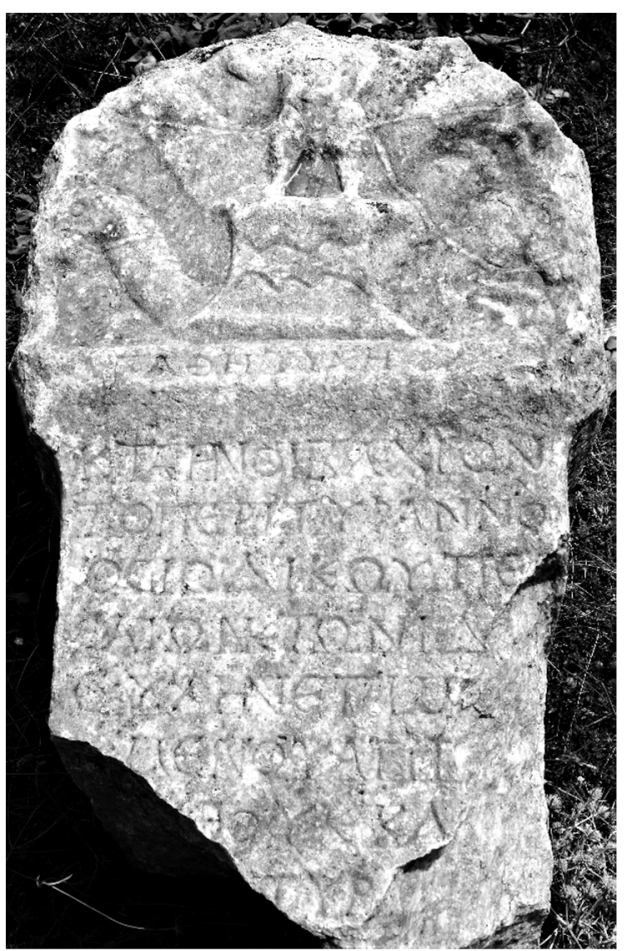

Fig. 1a

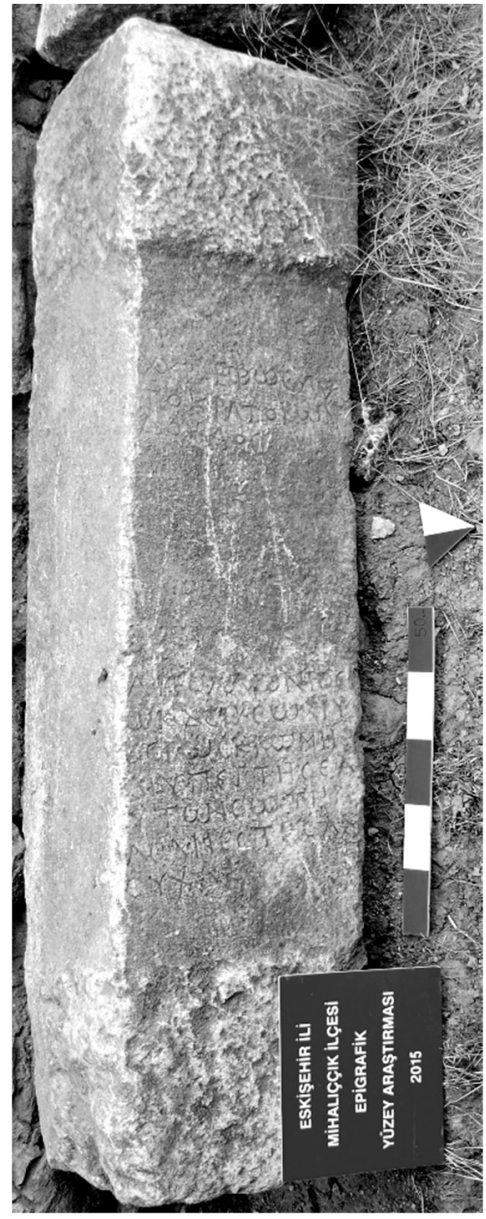

Fig. 2a

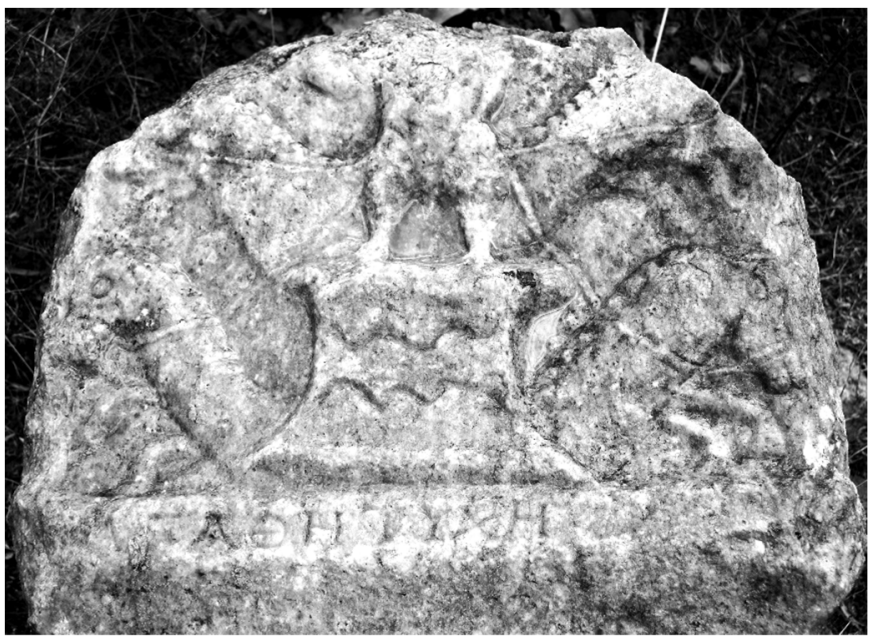

Fig. 1b

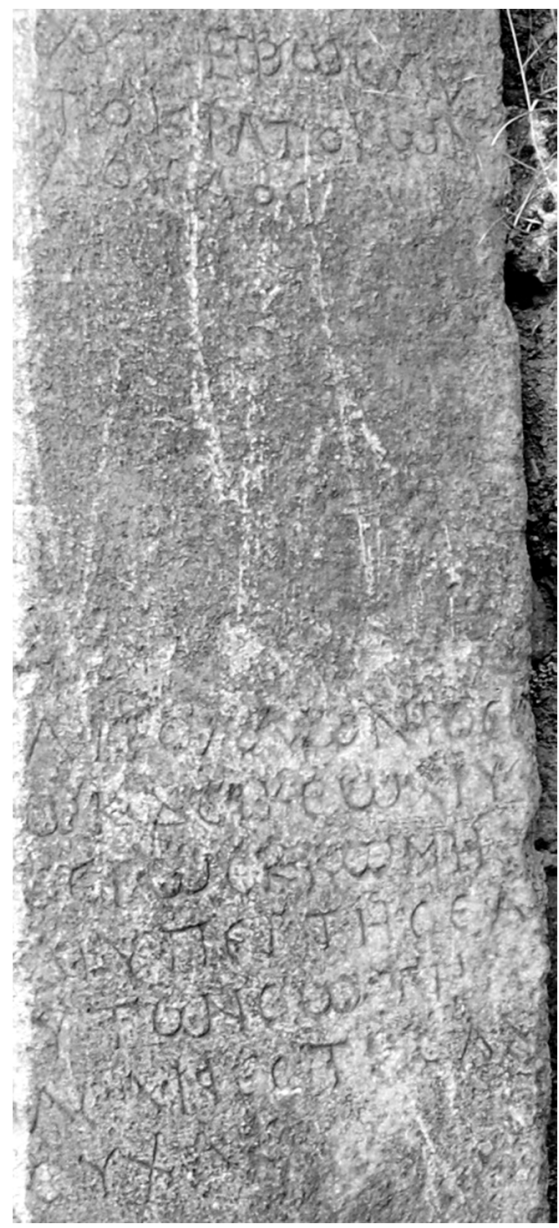

Fig. 2b 


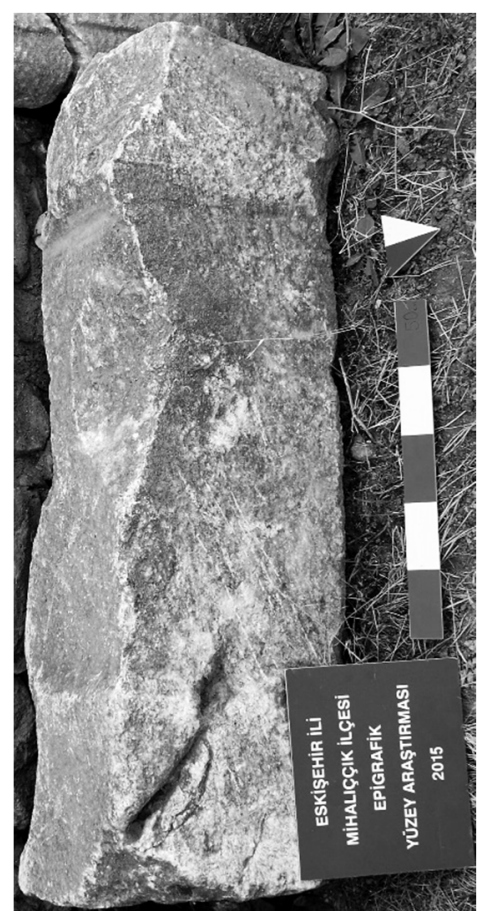

Fig. 3a

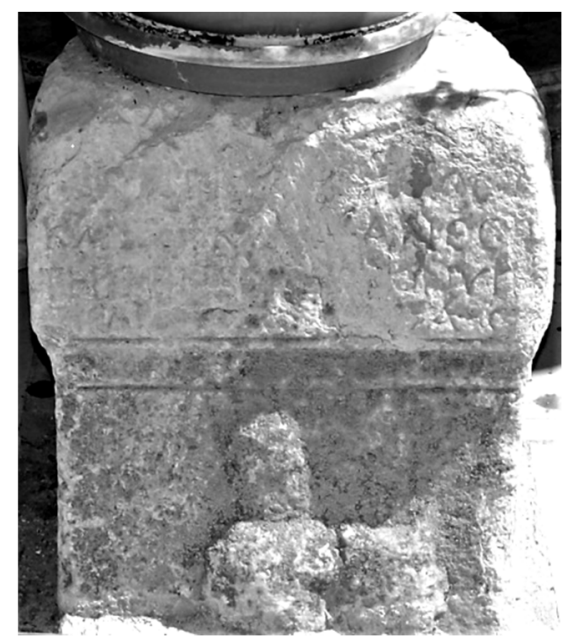

Fig. 4

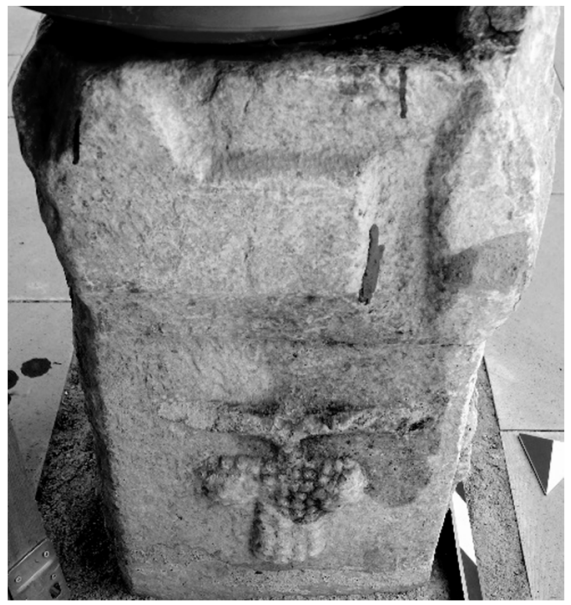

Fig. 5b

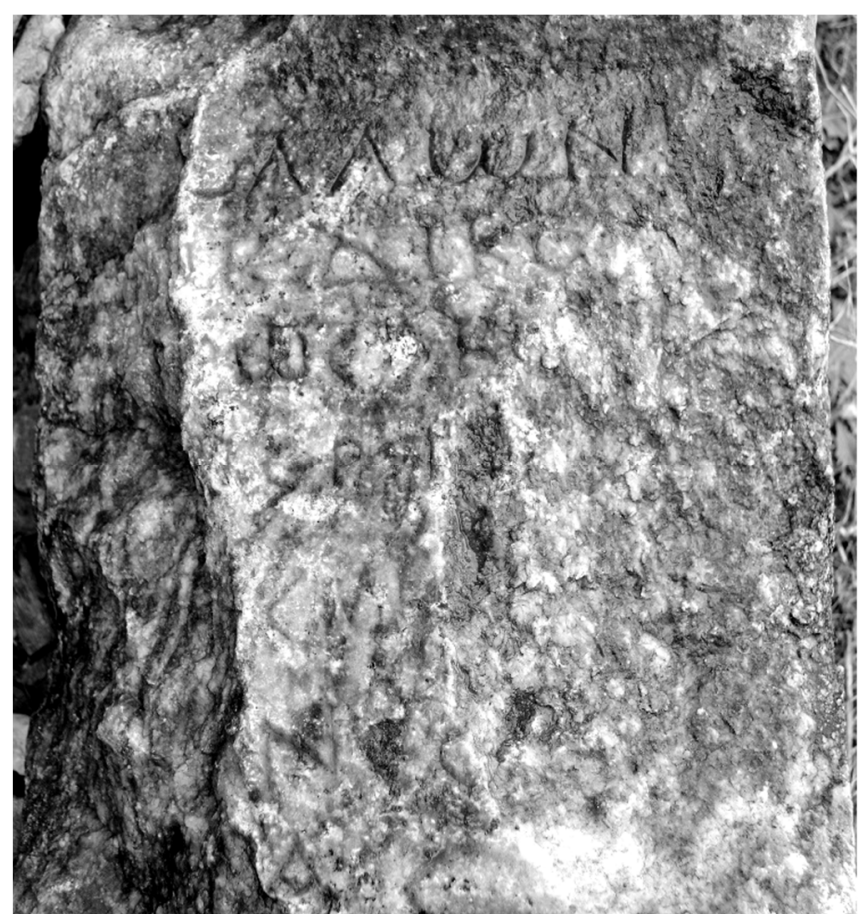

Fig. 3b

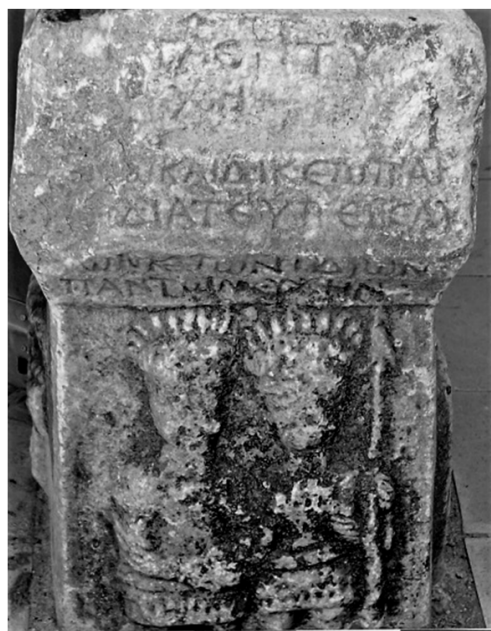

Fig. 5a

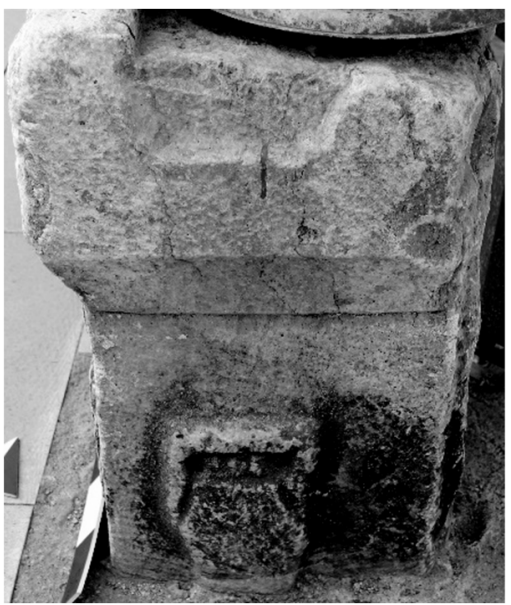

Fig. $5 \mathrm{c}$ 


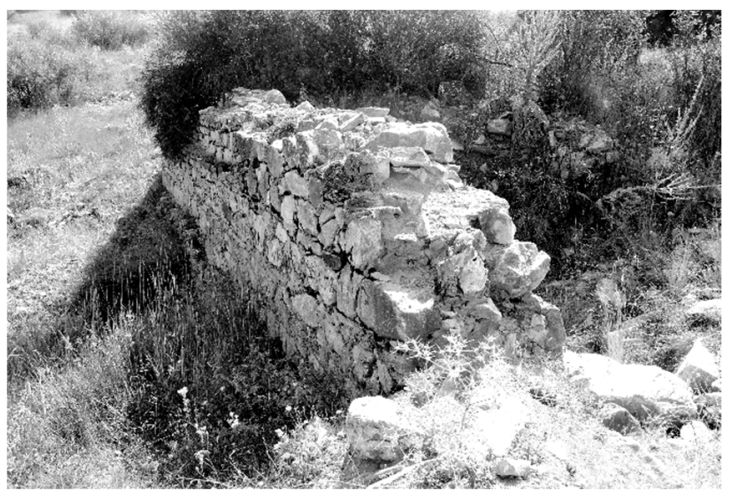

Fig. 6

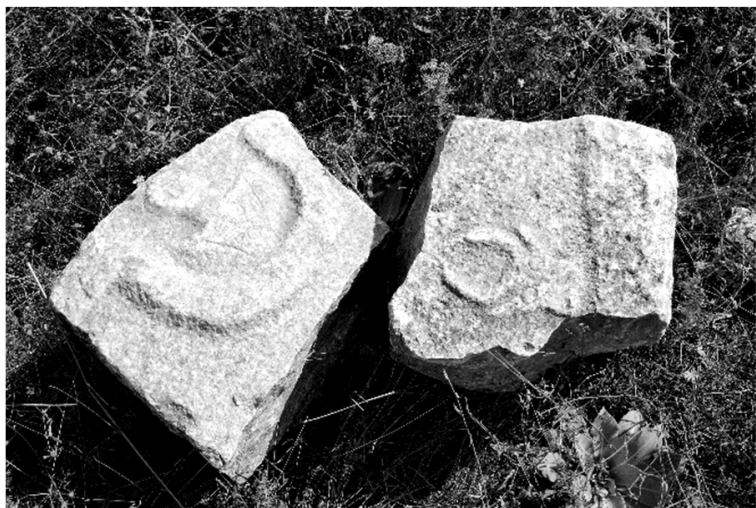

Fig. 8

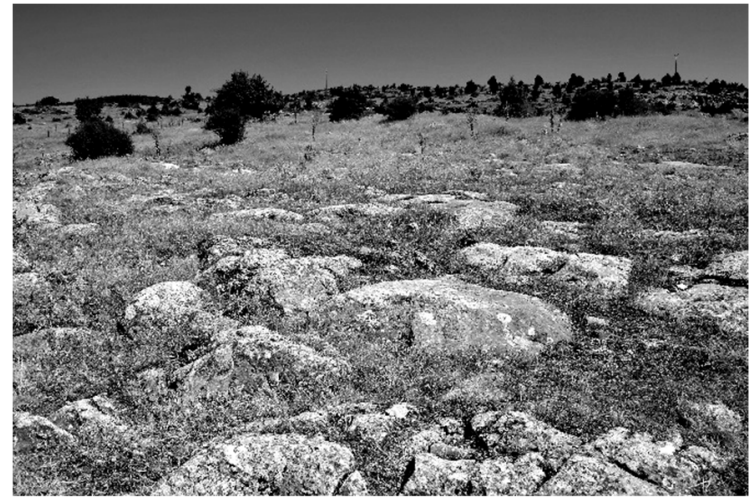

Fig. 10

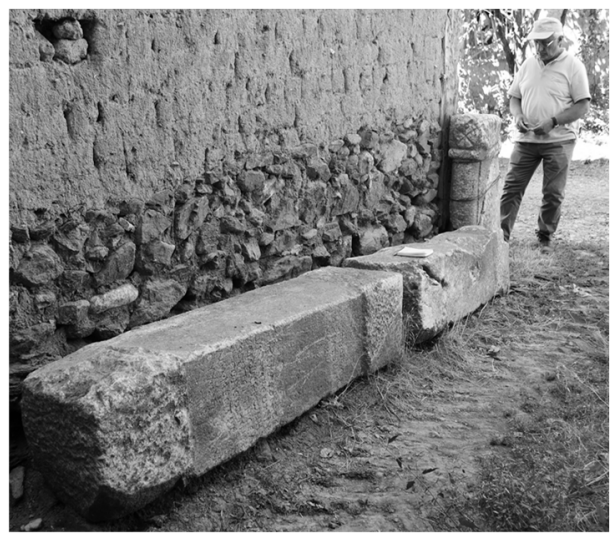

Fig. 12

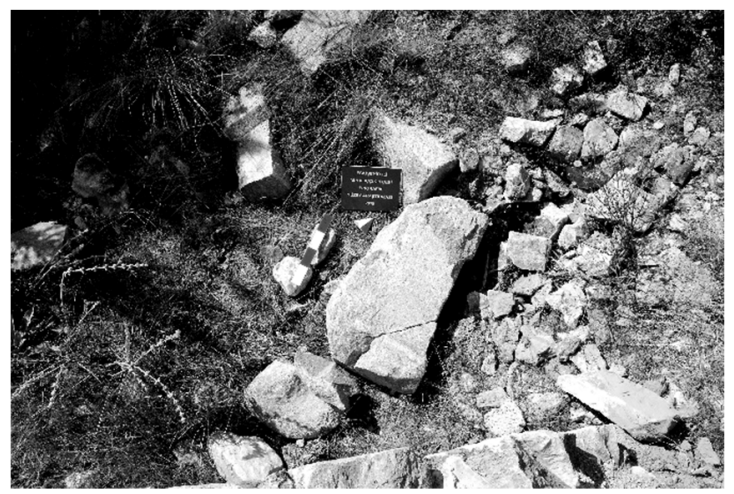

Fig. 7

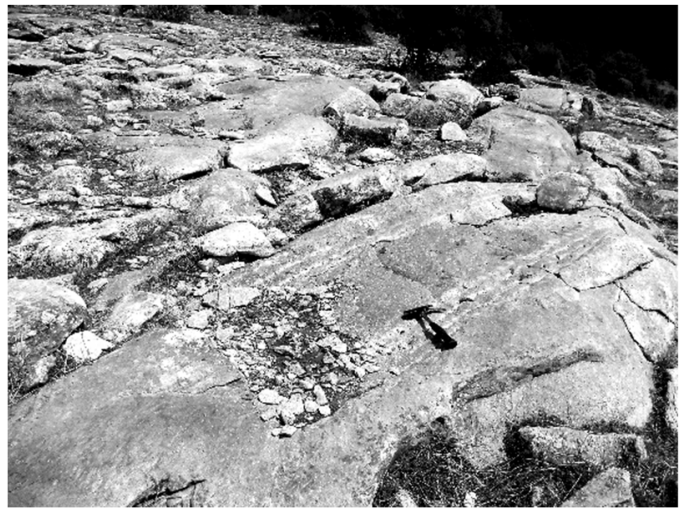

Fig. 9

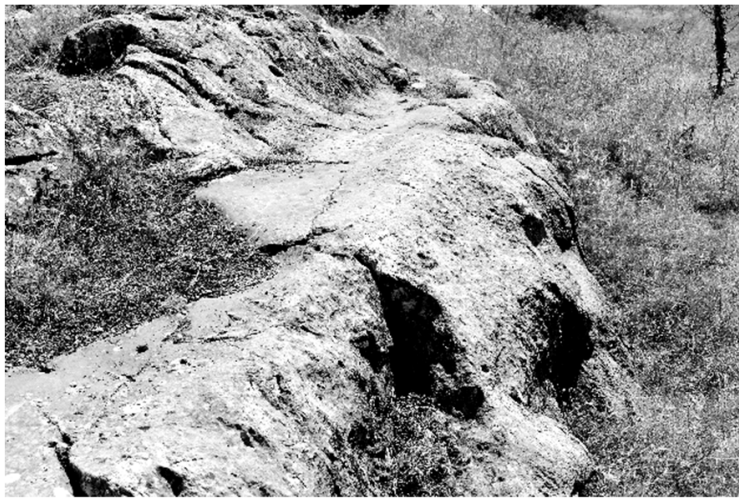

Fig. 11
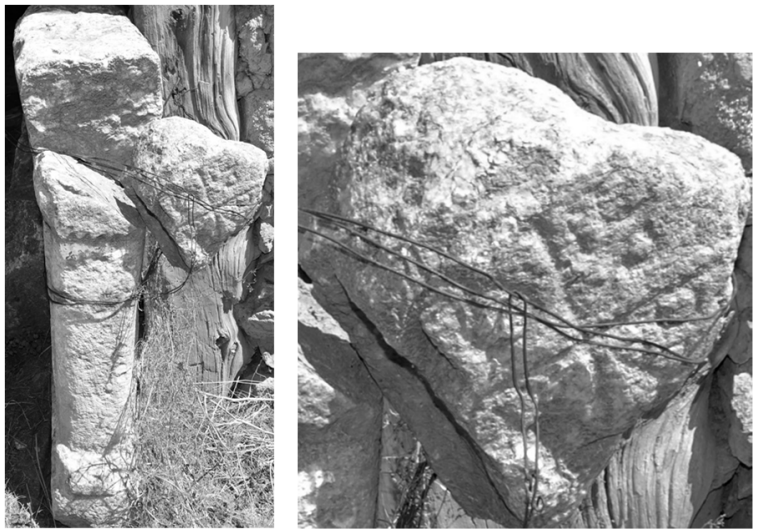

Fig. 13 